\title{
Roma oktatási helyzetkép Hargita megyében - pedagógusi viszonyulások
}

\author{
JAKAB JUDIT $^{1}$
}

\begin{abstract}
ABSZTRAKT
A tanulmány roma gyerekeket oktató pedagógusokkal készített interjúk alapján mutatja be azokat a pedagógusi attitűdöket és magatartásokat, amelyek a mindennapi oktatási gyakorlatot alakítják. Intézményes programok, infrastrukturális és személyi feltételek hiányában a pedagógusoknak személyesen kell megoldásokat találniuk az adódó nehézségekre. Így válnak az integrációs folyamat kulcsszereplőivé, és ezért viszonyulásaik, attitüdjeik meghatározóak a roma gyermekek iskolai eredményességének szempontjából. A kutatás célcsoportját olyan pedagógusok képezik, akik a Csíki-medence (Hargita megye, Románia) olyan általános iskoláiban tanítanak, ahol a roma tanulók aránya meghaladja a 25 százalékot. Az országos szakpolitika fontosabb irányainak jelzése és a székelyföldi magyar-roma viszonyt vizsgáló szakirodalom bemutatása szélesebb értelmezési keretet kínál a vizsgált témakörnek.
\end{abstract}

KULCSSZAVAK: Románia, roma oktatás, országos szakpolitika, Székelyföld, magyar-roma viszony, pedagógusi attitüdök

\section{ABSTRACT}

\section{The situation of Roma education in Harghita county - attitudes of pedagogues}

The study presents the attitudes and behaviours of pedagogues, based on interviews with teachers working with Roma children which constitute the quotidian educational practice. In absence of institutional programs, infrastructural and personal conditions, the teachers need to find solutions for the given difficulties. They become the key figures of the integration process and hence their attitudes and approaches are determining from the point of view of Roma children's school efficiency. The target audience of the research are composed by pedagogues, who teach in elementary schools in the Csiki Basin in Harghita county, where the rate of Roma learners exceeds 25 percents. Signalling the main directions of the national policy and the presentation of literature examining the Hungarian-Roma relationship in Szeklerland offer a broader framework for the interpretation of the subject.

KEYWORDS: Romania, Roma education, national policy, Szeklerland, Hungarian-Roma relationship, attitudes of pedagogues

\footnotetext{
${ }^{1}$ PhD hallgató, Debreceni Egyetem, Szociológia és Társadalompolitika Doktori Program.
} 


\section{TEMATIKUS TANULMÁNYOK - Székelyföld - térség és társadalom}

\section{Bevezetés}

A romák oktatásának szükségességéről értekezni szinte közhelynek számít, különösen, ha a vonatkozó országos dokumentumokat, tervezeteket és stratégiákat tanulmányozzuk. Az Európai Unióhoz való csatlakozással Romániának ${ }^{2}$ is igazodnia kellett azokhoz a nemzetközi szabályozásokhoz, előírásokhoz, amelyek kiemelten fontosnak tartják a romák helyzetének javítását és társadalmi integrációját. A kezdeti tapogatózások, tájékozatlanság után sorra alakultak a különböző bizottságok, intézmények, megszülettek az első stratégiák, majd azok módosításai, bővítményei. Elkezdődött a roma gyermekek tömeges beiskolázása, amely új helyzetet teremtett sok iskola számára. Ez a folyamat Székelyföldön, Hargita megyében is sok iskolának kihívást jelent, hiszen egyre több roma többségű csoport, osztály, iskola jön létre. Az iskolák felkészületlenek a feladatra, gyakran kényszerhelyzetben vannak, egyfelől be kell tartaniuk a vonatkozó törvényeket, előírásokat, másfelől hiányoznak azok az infrastrukturális és személyi feltételek, amelyek ezt lehetővé tennék. Hiányzik a szakmai megalapozottság, az összehangolt térségi, megyei roma politika, hiányoznak a befektetésekhez szükséges források. Intézményes programok, infrastrukturális és személyi feltételek hiányában a pedagógusoknak személyesen kell megoldásokat találniuk az adódó nehézségekre. Így válnak az integrációs folyamat kulcsszereplőivé, és ezért viszonyulásaik, attitűdjeik meghatározóak a roma gyermekek iskolai eredményességének szempontjából.

Tanulmányomban roma gyerekeket oktató pedagógusokkal készített interjúk alapján mutatom be azokat a pedagógusi attitűdöket és magatartásokat, amelyek a mindennapi oktatási gyakorlatot alakítják. A kutatás célcsoportját olyan pedagógusok képezik, akik a Csíki-medence (Hargita megye, Románia) olyan általános iskoláiban tanítanak, ahol a roma tanulók aránya meghaladja a 25 százalékot. Az országos szakpolitika fontosabb irányainak jelzése és a székelyföldi magyar-roma viszonyt vizsgáló szakirodalom bemutatása szélesebb értelmezési keretet kínál a vizsgált témakörnek.

Az első alfejezetben azokat az országos léptékű oktatáspolitikai intézkedéseket mutatom be, amelyeket a roma tanulók iskolai integrációjának támogatása céljából foganatosítottak. Az anyagi jellegú támogatások (ingyenes tanszer, ingyenes tej-kifli program) mellett figyelmet kapott a roma pedagógusképzés, a romani nyelvü tankönyvek és segédanyagok megjelentetése, a romák oktatásáért felelő tanfelügyelők és iskolai mediátorok kinevezése. A második alfejezetben azokat a fontosabb térségi kutatásokat tekintem át, amelyek a romák és a többségi magyar lakosság együttélési modelljeit, gazdasági kapcsolatait, a romák intézményekhez való viszonyulását, öndefiníciós kísérleteit vizsgálják. Ezek a kutatási eredmények az általam vizsgált témakör szélesebb értelmezési keretét biztosítják. A tanulmány további részében

\footnotetext{
${ }^{2}$ Románia 2007-ben csatlakozott az Európai Unióhoz.
} 


\section{TEMATIKUS TANULMÁNYOK - Székelyföld - térség és társadalom}

a Hargita megyei roma oktatás rövid bemutatása és a kutatás módszertanának ismertetése után előzetes kutatási eredményeimet mutatom be. A pedagógusokkal készített interjúk alapján a kirajzolódó pedagógusi attitűdöket és „stratégiákat” tipologizálom és értelmezem a társadalmi környezet kontextusában.

\section{Országos szakpolitika}

Az 1990-es években a román oktatás a nagy átszervezések, reformok korát élte, az előző rendszer hiányosságait, rendellenességeit próbálták korrigálni, törvényes, jogi kereteket szabni az új helyzet lehetőségeinek ${ }^{3} \mathrm{Ez}$ a folyamat igen nehézkesnek, ellentmondásosnak és összehangolatlannak bizonyult, az „átmeneti állapot” hosszasan elhúzódott. Az oktatási rendszer számára sokáig láthatatlan maradt a hátrányos helyzetűek, az iskolaelhagyók, a be nem iskolázottak egyre szélesedő tömege. Az abban a periódusban készülő, a roma családok helyzetét, a roma gyermekek iskolai beilleszkedését vizsgáló kutatások (Zamfir - Zamfir 1993, Jigau - Surdu 2002) elmélyülő szegénységről, nagyszámú iskolaelhagyásról, gyenge iskolai teljesítményekről számolnak be. Bár elszigetelten elindultak különböző kezdeményezések, főleg nemzetközi szervezetek finanszírozásával (pl. néhány roma nyelvű osztály, roma pedagógusok képzése), egyes kutatók ezt az időszakot a tapogatózások, a tájokozódás időszakaként tartják számon (Ionescu - Cace 2006).

Tulajdonképpen a kétezres évek elejétől, amikor Románia Európai Unióhoz való csatlakozásának szándéka egyre erősebben körvonalazódott, kaptak helyet a romániai kormányhatározatokban, kormánystratégiákban olyan EU-konform alapelvek, célkitűzések, amelyekben prioritásként jelenik meg az esélyegyenlőség elvének érvényesítése az oktatásban, a hátrányos helyzetű rétegek széleskörű beiskolázása, illetve az oktatásban való benntartása. A 2001-2002-es tanévtől minden szakiskolában, középiskolában osztályonként két-két helyet tartanak fenn roma tanulók részére. ${ }^{4}$ Szintén a kétezres évek elejétől néhány főiskola és egyetem (főleg szociális munkás-, pedagógus és rromani nyelvtanár jelölteknek) biztosít ingyenes helyeket roma fiatalok számára, és bár szórványosan, de elindult a roma pedagógusok képzése is, amely az évek során néhány egyetemre terjedt ki. A Megyei Tanfelügyelőségek kinevezték az első roma oktatásért felelő tanfelügyelőket (3363 sz. Határozat, 1999), akiknek a hatáskörébe tartozik az egyes megyék roma oktatásának szervezése, követése, vonatkozó statisztikai adatok begyűjtése. Megírásra kerültek az első roma nyelvű tankönyvek és segédanyagok, amelyeknek száma az évek során növekedett.

${ }^{3}$ Új Alkotmány -1992, új Tanügy Törvény - 1995 stb.

${ }^{4} \mathrm{~A}$ jelentkezőknek egy törvényesen bejegyzett roma párt vagy szervezet által kiállított ajánlással kell bizonyítaniuk, hogy roma nemzetiségüek. Több jelentkező esetén a legjobb tanulmányi átlaggal rendelkezők foglalhatják el a helyeket. 


\section{TEMATIKUS TANULMÁNYOK - Székelyföld - térség és társadalom}

Románia Európai Uniós csatlakozásával megsokasodtak azok a rendeletek, határozatok, amelyek a roma gyermekek iskolai integrációját szabályozzák. 2007-ben jelent meg az iskolai szegregáció megszüntetésére vonatkozó határozat (1540. sz. Határozat 2007), amelyet 2016-ban frissítettek. A 2014-2020-as időszakra vonatkozó kormánystratégia előirányozza az iskolai mediátor alkalmazását minden olyan iskolában, ahol a roma tanulók aránya több mint 15 százalék. Sajnos a gyakorlatban forráshiány miatt ez kevés településen valósulhat meg. A kormány, az egyes minisztériumok keretében különböző szakbizottságok, hivatalok, ügynökségek alakultak különböző stratégiák, programok, tervek megfogalmazása, megvalósítása céljából. Tehát ebben az időszakban fokozatosan kiépült az az intézményhálózat, amelynek faladata, felelőssége lett az EU-konform irányelvek „meghonosítása”, a romák helyzetének javítását célzó stratégiák elkészítése.

Az egyes nemzetközi szervezetek jelentései, a kapcsolódó kutatások eredményei azt mutatják, hogy a különböző stratégiák célkitűzései közül nagyon kevés valósul meg (Moisa 2016, World Bank Jelentés 2014). Az iskolák hétköznapi valóságában nehezen érvényesülnek a deklarált alapelvek, célkitűzések, a roma gyermekek iskoláztatása nagyon sok nehézségbe ütközik. Az okok sokrétűek, elsősorban hiányoznak azok a konkrét operatív programok, amelyek lehetővé tennék a stratégiák életbeültetését. Ugyanakkor az egyes lépésekhez nincsenek hozzárendelve a források, azok biztosítását gyakran a helyi önkormányzatokra hárítják. Az általában szűkös költségvetésű önkormányzatok nem tudják előteremteni a szükséges összegeket, ezért sok esetben elmaradnak az intézkedések (Ionescu - Cace 2006, Moise 2016). Ez különösen érvényes azokra a vidéki településekre, ahol a romák nagy számban élnek. A stratégiák tartalomelemzését végző kutatók (Moisa 2016) szerint a célkitűzések megfogalmazása is nagyon általános, hiányoznak a konkrét adatok, amelyek segítenék a tervezést, az eredményesség mérését. Hiányzik az összehangoltság az egyes szektorok között, az eredmények gyakran egy-egy személy elköteleződésének, kitartásának és szakértelmének köszönhetőek.

\section{Székelyföldi helyzetkép}

Székelyföld viszonylatában hiányoznak a roma népességet, annak identitásépítési gyakorlatát, életmódját, többségi társadalomhoz való viszonyát vizsgáló átfogó, rendszeres kutatások. Az eddigi kutatások egy-egy település vagy településcsoport roma lakosságát vizsgálják különböző szempontok szerint, amelyek többnyire esettanulmányok formájában adnak bizonyos képet a romák etnikai hovatartozásáról, egy-egy település etnikai térszerkezetéről, mások pedig az etnikai identitás és a felekezeti hovatartozás közötti összefüggéseket elemzik, vagy az együttélést befolyásoló tényezőket teszik vizsgálat tárgyává (Biró A. - Bodó - Gagyi - Oláh - Túros 1996, Biró A. - Bodó - Gagyi - Oláh 2002, Fosztó 2003, Kinda 2007, Pozsony 2003, Szabó Á. 


\section{TEMATIKUS TANULMÁNYOK - Székelyföld - térség és társadalom}

2002). A roma népesség igen heterogén, a különböző vidékeken, különböző településeken élő helyi roma társadalmak hierarchikus szerveződésűek, „a társadalmi rang körükben nemzedékrôl-nemzedékre öröklődik" (Biró - Oláh 2002:29). A lakóhelyül szolgáló település földrajzi, gazdasági, társadalmi tényezői szintén meghatározzák a helyi roma közösség helyzetét, a roma-magyar viszonyok alakulását. Az egyes kutatási eredmények nem általánosíthatóak, a lokális szintű vizsgálatok elengedhetetlenek.

A csíkszeredai KAM - Regionális és Antropológiai Kutatások Központjának kutatói több program keretében is végeztek roma kutatásokat székelyföldi, főleg Hargita megyei településeken. A két kötetben ${ }^{5}$ is megjelenő tanulmányaik alapján körvonalazódik egy mozaikszerü helyzetkép a romák létfenntartási módozatairól, a romák és a többségi magyar lakosság együttélési modelljeiről, a romák intézményekhez való viszonyulásáról, a térfelosztás változásairól, a romák öndefiníciós kísérleteikről. Összegző tanulmányaikban (Biró - Oláh 2002, Oláh 1996) egy sor fontos következtetést fogalmaznak meg, amelyek alapját képezhetik a további vizsgálatoknak és irányt szabhatnak bizonyos fejlesztéspolitikai lépéseknek.

A rendszerváltozás után változások sorozata indult el a roma közösségekben (létszámbeli növekedés, belső rétegződés, migráció felerősödése, intézményekhez való viszony módosulása, öndefiníciós kísérletek, amelyek a magyar-roma viszony alakulását is befolyásolják. Az 1989 előtti roma-magyar „egy más mellett élési” modellt fokozatosan felváltja „az egyre több ponton egymásba csúszó” két világ, amely a "tranzakciós költségek” növekedését eredményezi a magyar népesség körében, amelyet ők „veszteségként” élnek meg (Biró 2017).

A rendszerváltozás után az önálló gazdálkodásra visszatért magyar háztartások és a roma családok között az együttmúködések, kölcsönös kapcsolatok hálózata bizonyos településeken meggyengült, amely a roma-magyar viszony társadalmi aspektusát is befolyásolta (Biró - Oláh 2002). Máshol az előző rendszerben bejáratott a magyar patrónus - roma kliens viszony 1989 után is fennmaradt, a romák napszámosként dolgoznak gazdáknál. Ezek szigorúan aszimmetrikus munkakapcsolatok, nincsenek személyes vonatkozásaik (Kiss 2009, Kulcsár - Varga - Obádovics 2013). Ugyanakkor vannak települések, ahol a „romák közül kiemelkedett egy elit réteg, amely hatékonyabb stratégiái következtében nagyobb tőkeerővel rendelkezik, mint a magyar gazdák" (Szabó Á. 2002:215). A magyar-roma gazdasági kapcsolatokat elemezve Szabó Á. Töhötöm megállapítja, hogy az általa vizsgált székelyföldi településen már nem kizárólag a korábban jellemző magyar patrónus-cigány kliens viszony működik, hanem megjelentek a cigány patrónus-magyar kliens viszonyok,

\footnotetext{
${ }^{5}$ Gagyi József (szerk.): Egymás mellett élés. A magyar-román, magyar-cigány kapcsolatokról (1996), KAM - Regionális és Antropológiai Kutatások Központja. Pro-Print Könyvkiadó. Csíkszereda, illetve Bodó Julianna (szerk): Helykeresők? Roma lakosság a Székelyföldön (2002) KAM - Regionális és Antropológiai Kutatások Központja. Pro-Print Könyvkiadó. Csíkszereda.
} 


\section{TEMATIKUS TANULMÁNYOK - Székelyföld - térség és társadalom}

valamint az egyenrangú gazdasági kapcsolatok is. És bár „a gazdasági érdek kimozdítja a romák megítélésére vonatkozó korábbi mentalitást merevségéből, de átstrukturálni azt nem képes” (Szabó Á. 2002: 215). Ugyanerre a következtetésre jut Peti Lehel (2007) is egy Kis-Küküllő menti településen végzett kutatásában. „A cigányság adaptációs törekvései és sikerei ellenére sincsenek alapvető jelentőségú módosulások a cigányokról alkotott kép vonatkozásában. A cigányoknak a magyarokhoz tudatosan igazodó életformája, a gazdasági különbségek csökkenése, esetenkénti kiegyenlítődése, vagy éppen a cigányok javára billenése sem tudja megváltoztatni a cigánysággal kapcsolatos, súlyos elöítéletekkel terhes mentális beállítódásokat" (Peti 2007: 170). A rendszerváltást követő években felgyorsult a romák körében a belső rétegződés, ezt sokszor a külföldi munkavállalás segítette elő. „A téglavetői gyakorlat és a migráció sajátos összefonódása eredményeképpen a cigány csoporton belül horizontális törésvonalak jöttek létre, a gazdasági helyzetek kétpólusossága kiélezetté (nagyon gazdag - nagyon szegény) vált" - állapítja meg Kinda István a 2004-2005-ben végzett, a társadalmi rétegződésre és a gazdasági stratégiákra vonatkozó nagyborosnyói (Háromszék) kutatása nyomán (Kinda 2007: 619). A kutatások eredményei arra engednek következtetni, hogy egyes településeken körvonalazódnak bizonyos modernizációs, integrációs törekvések a roma népesség részéről, annak ellenére, hogy ezek sok esetben a többségi lakosság ellenszenvével, elutasításával találkoznak. Ezek a folyamatok településenként, csoportonként más-más fázisban vannak, és nem föltétlenül a különböző hivatalos intézmények (iskola, egészségügyi intézmények, önkormányzatok) modernizáló, integráló hatásának a következményei, hiszen a roma lakosság „a társadalmi környezet intézményes modernizációs ajánlatának jelentösebb részével szembehelyezkedik, vagy csak részlegesen él ezekkel a lehetőségekkel" (Biró 2017: 147).

\section{Oktatási gyakorlat, pedagógus viszonyulások Hargita megye példáján}

A többségi magyar lakosság romák iránti ellenszenve, előítéletes beállítódása igen megnehezítette (megnehezíti) az iskolák integrációs törekvéseit is, hiszen az adott helyzetben az iskola gyakorlatilag képtelen olyan „befogadó közeget” teremteni a roma tanulóknak, ahol ők elfogadottnak és befogadottnak érezhetnék magukat. Nem ritka, hogy a magyar szülők egy jelentős része inkább a szomszéd településre vagy a közeli városi iskolák valamelyikébe íratja át gyerekét. A spontán migráció nyomán pedig egyre nagyobb számban jöttek (jönnek) létre a roma többségű osztályok. A 2014-2015-ös tanévben Hargita megye 78 iskolai intézményében 261 olyan csoport vagy osztály volt, ahol a roma tanulók aránya meghaladta a 25 százalékot (Tanfelügyelőségi beszámoló 2014-20156).

\footnotetext{
${ }^{6}$ Nyilvánosan nem jelent meg.
} 


\section{TEMATIKUS TANULMÁNYOK - Székelyföld - térség és társadalom}

A Hargita Megyei Tanfelügyelőség évente begyűjti a megye iskoláitól a roma tanulók, diákok számára vonatkozó adatokat A roma tanulók számának megállapítása az iskolákban nagyon gyakran ún. szakértői besoroláson alapul, sok esetben az iskolák vezetősége vagy a pedagógusok döntik el, hogy kit tekintenek romának. Ez magában hordozza annak a lehetőségét, hogy az intézmény szempontjából „problémásnak” ítélt romák gyerekei, azaz szociális segélyezett, roma negyedekben, roma telepeken lakó családok, gyenge iskolai eredményeket felmutató tanulói kerülnek az adatbázisba, és kimaradnak azok az integrálódott „házi cigányok”, akik a települések „belsejében” laknak, akik a többségi magyar lakosság életvitelét követik és rendszeresen járatják gyerekeiket iskolába. A statisztikák az óvodák, általános iskolák, szakiskolák és középiskolák roma tanulóinak, diákjainak összesített adatait tartalmazzák.

1. táblázat: Beiskolázott roma tanulók és diákok száma Hargita megyében (fó)

\begin{tabular}{|c|c|c|c|c|c|c|c|c|c|c|c|}
\hline Tanév & $\begin{array}{c}2006- \\
2007\end{array}$ & $\begin{array}{c}2007- \\
2008\end{array}$ & $\begin{array}{c}2008- \\
2009\end{array}$ & $\begin{array}{c}2009- \\
2010\end{array}$ & $\begin{array}{c}2010- \\
2011\end{array}$ & $\begin{array}{c}2011- \\
2012\end{array}$ & $\begin{array}{c}2012- \\
2013\end{array}$ & $\begin{array}{c}2013- \\
2014\end{array}$ & $\begin{array}{c}2014- \\
2015\end{array}$ & $\begin{array}{c}2015- \\
2016\end{array}$ & $\begin{array}{c}2016- \\
2017\end{array}$ \\
\hline $\begin{array}{c}\text { Roma } \\
\text { tanulók, } \\
\text { diákok } \\
\text { száma }\end{array}$ & 1167 & 2503 & 3581 & 3909 & 3720 & 3634 & 3779 & 4084 & 3809 & 4544 & 4501 \\
\hline
\end{tabular}

Forrás: Saját szerkesztés a Hargita Megyei Tanfelügyelőség adatai alapján

Az Országos Statisztikai Hivatal adatai alapján Hargita megyében 2017-ben az általános iskolákban tanulók 85,75 százaléka magyar nyelven, a maradék 14,25 százalék román nyelven tanult (INSS). A romák általában jól beszélik a mellettük élő többségi lakosság nyelvét, a székelyföldi (Kovászna, Maros, Hargita) megyékben élő roma lakosság kétharmada magyar nyelven is beszél, és a népszámlálások során gyakran magyarnak vallja magát. 2011-ben 56 százalékuk vallotta magát magyarnak (Kiss - Barna 2012). Hargita megyében többségük magyar iskolába járatja gyerekeit.

A „standard” oktatásra berendezkedett iskolákat, pedagógusokat felkészületlenül érte az új helyzet, a korábban bejáratott módszerek gyakran nem müködtek, megsokasodtak a fegyelmi gondok, betarthatatlanná váltak a tantervi elöírások. A helyzet szakszerű kezelésének a térségben nem voltak előzményei, hiányoztak (hiányoznak) a szakmai segítséget nyújtó szakemberek, fórumok, a pedagógusok nem rendelkeztek ilyen jellegű képzettséggel. Románia Európai Uniós csatlakozása után megsokasodtak azok a projektek, amelyek a „veszélyeztetett csoportok” életkörülményeinek javítására, a hátrányos és/vagy roma gyermekek oktatásának támogatására irányultak (beiskolázás, nyári óvodáztatás, iskoláztatásukhoz szükséges felszerelések, ruházat biztosítása, roma pedagógusok képzése). A projektek befejeződése után nagyon kevés településen tudta felvállalni az iskolafenntartó a programok folytatását, így azok általában megszűntek (saját kutatási tereptapasztalat). Mi- 


\section{TEMATIKUS TANULMÁNYOK - Székelyföld - térség és társadalom}

vel a vonatkozó oktatáspolitikai dokumentumokban megfogalmazódó célkitűzések megvalósításához nincs hozzárendelve a finanszírozás és a konkrét koncepció (Moisa 2016, World Bank Jelentés 2014: 27), a roma gyermekek beiskolázásával megjelenő problémák sokaságával (szociális jellegű nehézségek, az eltérő szocializációból fakadó különbségek, nyelvi nehézségek, az óvodáztatás hiánya, az alacsony tanulási motiváció, a szülőkkel való kommunikáció nehézségei, a nem roma közösség elutasítása) gyakran a pedagógusok szembesülnek, akik saját elköteleződésük, szakértelmük, problémamegoldási készségük függvényében megpróbálták (megpróbálják) kezelni a helyzeteket.

\section{A romák oktatása és a pedagógusok}

A magyarországi és nemzetközi kutatási eredmények (Falus et al. 1989, Polónyi Timár 2001, Hanushek - Kain - Rivkin 2005) egybehangzóan azt bizonyítják, hogy az oktatásban a legfontosabb tényező a pedagógus minősége. A tanulói teljesítményt leginkább a tanár személyisége, elkötelezettsége, kommunikációs és a csapatmunkára való képessége, a gondolatok átadásának kompetenciája befolyásolja, és csak kevésbé meghatározó a pedagógus végzettsége, szaktárgyi tudása, a tanításban szerzett gyakorlatának hossza.

Számos kutatási eredmény (Deci - Ryan 2008, Wigfield et al. 2006) bizonyítja, hogy azok a pedagógusok tudják diákjaikat „megtartani”, motiválni, tanulásra ösztönözni, akik bíznak tanítványaikban, akik meg tudják teremteni a hatékony tanuláshoz szükséges megfelelő érzelmi légkört, akik segítséget nyújtanak a továbblépéshez, akik elkötelezettek a tanítás iránt. A tanulók pedagógushoz való kötődése szintén pozitív hatással van az iskolai motiváció alakulására, az elköteleződés fenntartására (Deci - Ryan 2008, Howes 2000). Eccles (2004) az iskolai értékelés motiváló/demotiváló szerepére hívja fel a figyelmet. Ha az értékelés csak a végső teljesítményre vonatkozik, és nem veszi figyelembe a tanulási folyamatot, könnyen motiválatlansághoz vezethet azoknál a tanulóknál, akik bizonyos okok miatt (egyéni sajátosságok, szülői támogatás hiánya) bár próbálkoznak, mégsem nyújtanak kimagasló teljesítményt. Megállapítja, hogy „az iskolai értékelési rendszer nem méltányolja a tanulási folyamatba fektetett erőfeszítés jutalmazásának lehetőségét, így a pedagógusok gyakorlatának sem válik részévé. Bár fontosságát felismerik, ritkán alkalmazzák (Eccles 2004, idézi Kacsó-Dávid 2017: 51).

Egyes kutatók (Bacskai 2015) arra is rámutattak, hogy az alacsony státusú diákkompozíciójú iskolákban a pedagógusok gyakran az átlagosnál szélesebb körű szerepelvárásokkal találkoznak az intézményekben, speciálisak a munkakörülményeik, más módszerekkel tudnak eredményeket elérni, és hogy speciális felkészítést és szakmai segítséget igényelnek. Ugyanakkor előfordul, hogy a középosztálybeli ta- 


\section{TEMATIKUS TANULMÁNYOK - Székelyföld - térség és társadalom}

nár és a más szellemi és anyagi (más etnikai) háttérből érkező diák kultúrája olyan mértékben eltér, hogy az megnehezíti a tanuláshoz szükséges légkör kialakítását, a pedagógiai feladatok ellátását (Nagy J. 2002).

Liskó Ilona a roma tanulókat tömörítő iskolákban végzett kutatás ${ }^{7}$ eredményeiről készített tanulmányában a pedagógus közvetítő szerepének nehézségeire világít rá, és számbaveszi azokat a "feladatokat”, amelyekkel a roma gyerekeket nagy létszámban oktató iskolák pedagógusai szembesülnek: „az átlagosnál szegényebb családi környezet miatt keletkezett szociokulturális hátrányok kompenzálása; a többségi társadalométól eltérő szokások és viselkedésmódok elfogadása; a többségi társadalométól eltérő családi értékrend elfogadása; a nyelvi hátrányok kompenzálása; a kisebbségi létből és a többségi társadalom elöítéleteiből fakadó komplexusok és frusztrációk kezelése; a nem cigány környezet (például szülők és gyerekek) részérôl megnyilvánuló előítéletes magatartás megváltoztatása; a saját előítéletek leküzdése" (Liskó 2001: 35). A szerző arra is felhívja a figyelmet, hogy a feladatok társadalmi és szociálpszichológiai szempontból is rendkívül „kényesek”, és a pedagógusok munkája csak akkor lehet eredményes, ha mind a roma gyermekek, mind a szüleik elfogadják a pedagógust és kialakul egyfajta kölcsönös bizalom. A roma szülők és gyerekek, ha előítéletességet éreznek a pedagógusok részéről, elutasítással, ellenállással reagálnak rá. Az elutasító, diszkriminatív magatartások hatására csökken tanulási motivációjuk, közvetve pedig az iskolai eredményességük is. Az előítéletesség a tanulók önértékelésére is negatívan hat, ugyanakkor zavart, szerepkonfliktusokat, szégyenérzetet vált ki a gyerekekből (Liskó 2001).

Babusik a romák oktatásában az iskolai hatékonyság kulcstényezőit vizsgálva arra kereste a választ, hogy a sikeresség milyen arányban függ az iskola múködési paramétereitől (iskolaszervezet), a roma tanulók szociális hátterétől, az iskolában tanító pedagógusok értékvilágától és szemléletétôl (Babusik 2003). Megállapította, hogy a roma tanulók releváns továbbtanulási esélye az intézmény, a pedagógusok, valamint a környezet mint komplex rendszer eredménye. Szoros pozitív kapcsolatot fedezett fel a pedagógusok felsőoktatási képzés keretében abszolvált romológiai képzési ideje és az iskolai eredményességük között. Azok a pedagógusok, akik nagyon eredményes iskolában dolgoznak és rendelkeznek romológiai képzettséggel, kétszer kisebbnek ítélték meg a romák és nem romák közötti konfliktusokat, ugyanakkor az átlagnál lényegesebben pozitívabb viszonyt, elfogadást jeleztek a cigányokkal kapcsolatban (Babusik 2003: 34). A kutatás keretében a pedagógiai szemléletmód, stílus elemzésének vizsgálata nyomán a szerző arra a következtetésre jutott, hogy a pedagógusok „értékvilága, attitűdjei meghatározzák magát a pedagógiai munka

${ }^{7}$ A kutatásban az MTA Szociológiai Intézetéből Kemény István és Havas Gábor, az Oktatáskutató Intézet részéről pedig Fehérvári Anikó és Janni Gabriella vettek részt. A kutatás mintájában 192 olyan általános iskola szerepelt, ahol 1993-ban 25\% fölött volt a cigány tanulók aránya. 


\section{TEMATIKUS TANULMÁNYOK - Székelyföld - térség és társadalom}

egész folyamatát, következésképp mélyen kihatnak a tanulókkal elért eredményekre”, illetve a pedagógusok „romológiai képzettsége növeli a megfeleló pedagógiai eljárások használata iránti igényszintjüket" (Babusik 2003: 35-36).

\section{A kutatás módszertana}

A Debreceni Egyetem Humán Tudományok Doktori Iskolájának keretében készülő kutatásom témája „Roma gyermekek oktatása - pedagógusi attitúdök vizsgálata a Csíki-medencében (Hargita megye, Románia." Kutatásom egyik alapkérdése, hogy vajon a pedagógusok mennyire vannak tudatában a roma gyermekek iskoláztatásában betöltött kulcsszerepüknek? Hogyan viszonyulnak az új helyzet kihívásaihoz, az átlagosnál szélesebb körü szerepelvárásokhoz? Tudnak-e azonosulni szerepükkel, milyen szerepkonfliktusokat fogalmaznak meg, milyen stratégiáik vannak ezek feloldására? Mit tekintenek sikernek, miben látják saját „hozzáadott értéküket”?

\section{a) A MINTA}

A Hargita Megyei Tanfelügyelőség 2016/2017-es tanévre vonatkozó, a roma tanulók számát tartalmazó adatbázisból választottam ki azokat a Csíki-medencében ${ }^{8}$ található általános iskolákat, amelyekben a roma tanulók aránya 25 százalék fölött van. Négy intézmény került kiválasztásra, amelyek közül egy városi, a többi pedig vidéki iskola. Iskolánként 7-8 pedagógussal készítettem félig strukturált interjút, összesen 31 interjú készült. A pedagógusok kiválasztásánál arra törekedtem, hogy minél több „kategória” (településtípus, életkor és régiség, alsó tagozatos-felső tagozatos, vizsgatantárgyat tanító-készségtárgyakat tanító, csak roma osztályban-vegyes osztályban tanító) képviseltesse magát. A megkérdezett pedagógusok egyharmada alsó tagozatos tanító, a többiek felső tagozatos tanárok. A felső tagozatos tanárok fele osztályfőnök is. A megkérdezettek közül heten olyan osztályokban tanítanak, ahol csak roma gyermekek tanulnak. Tanítási régiségüket tekintve kétharmaduk több mint húsz éve van a pedagóguspályán, negyedük fiatalabb (kevesebb, mint tíz éve vannak a pályán), nyugdíjkorhatárhoz közeliek alig ketten vannak.

${ }^{8}$ A Csíki-medence egy 600-700 m magasságban elterülő hegyközi medence Hargita megyében (Románia), amely a Hargita-hegység és a Csíki-havasok között húzódik. Három részre oszlik: Felcsík, Középcsík és Alcsík. A választóvonal a régió legnagyobb települése, Hargita megye megyeközpontja, Csíkszereda. 


\section{TEMATIKUS TANULMÁNYOK - Székelyföld - térség és társadalom}

\section{b) MÓDSZEREK}

A pedagógusokkal készített interjúban két fő dimenzió mentén fogalmaztam meg kérdéseket. Az első részben a pedagógusszerepből adódó viszonyulás vizsgálatára irányuló kérdések (szakmaiság, tudatosság, megújulás, rugalmasság, szerepfelfogás, szerepkonfliktusok, feloldási stratégiák), a második részben a pedagógusok saját emberi viszonyulását, attitűdjét vizsgáló kérdések (munkával való megelégedettség, munkával való azonosulás, szervezet iránti elkötelezettség, hiedelmeik, meggyőződéseik, sztereotípiáik) kaptak helyet. A beszélgetés végén a pedagógusok a helyzet javítását célzó javaslataikat is elmondhatták. Az interjúzás és feldolgozás során segítségemre volt a több éves pedagógusi tapasztalat, és egyes térségi roma közösségek helyzetének alapos ismerete.

\section{Előzetes kutatási eredmények}

A pedagógusok roma oktatással kapcsolatos vélekedéseit, attitűdjeit vizsgálva az előzetes kutatási eredményeim azt mutatják, hogy igen változatos a viszonyulások palettája. A megkérdezett pedagógusok többsége kiemelten fontosnak ítéli meg a pedagógus személyének szerepét ebben a folyamatban, de a sikeresség és az ahhoz való személyes hozzájárulás értelmezésekor sokkal árnyaltabb a kép. Az eddig készített interjúk alapján kirajzolódni látszanak bizonyos típusok, amelyek fóbb jellemzőit mutatom be röviden a továbbiakban.

Az elkötelezett típus, aki a roma gyermekek mindennemű nehézségén megpróbál segíteni (étkeztetésben, ruháztatásban, tisztálkodásban is) és nemcsak az oktatást, nevelést tekinti feladatának. Egyfajta küldetéstudattal közelít a problémához és segíteni akarása, megértése folyamatosan arra sarkallja őt, hogy a gyermek érdekeit helyezze a középpontba, és annak rendelje alá egész oktató-nevelő munkáját. Ô az, aki a hivatalos tantervi előírások ellenére hozzáigazítja a tananyagot a gyermekek szintjéhez, aki a szabályzatok alkalmazásánál figyelembe veszi az egyéni „kilengéseket”, és gyakran „nem-hivatalos megoldásokat” talál egy-egy probléma orvoslására. „Hiányozgattak. (...) Akkor még a késéssel sem voltam szigorú. Azóta egyik nagy eredménynek tekintem, hogy már elérik a buszt, nem késnek el" (tanító 4). Az értékelésnél eltekint a standard teljesítményleírásoktól, és a fejlődést, előrehaladást a gyermek korábbi teljesítményéhez viszonyítja. Ő inkább a gyermekkel való közvetlen kapcsolatot, a bizalom kialakítását, a megértést, a gyermek lelkének „megérintését” tekinti elsődleges céljának, és jól kommunikál mind a gyermekekkel, mind a szüleikkel. „Fontos, hogy emberként szóba állj velük, s akkor befogadnak. Legyen kapcsolat, beszélgetés. (...) Csak türelemmel és szeretettel lehet. Szerintem gyönyörködni kell a gyermekbe" (tanító 1). Eljutott oda, hogy már kevésbé frusztrálják őt a rendszer elvárásai, nem akar mindenáron megfelelni az előírásoknak. „Ha a tantervet akarod 


\section{TEMATIKUS TANULMÁNYOK - Székelyföld - térség és társadalom}

követni, az csak stresszt okoz. Én magamnak beosztom, hogy mi a mai célom, holnap a holnapi célom. Van, hogy mindig azt se teljesítem" (tanító 1). A beszélgetéseim során kevés ilyen típusú pedagógussal találkoztam, többnyire az elemiben tanító pedagógusok között voltak néhányan (négyen), akik általában csak roma gyermekekkel dolgoznak, lehetőleg fizikailag is távol a „központi” számonkérésektől, ellenőrzésektől. Több mint húsz éve dolgoznak pedagógusként, és személyre szabott módszereikkel sok roma tanulót, ha szükséges, több év alatt, tanítanak meg írni-olvasni. Ugyanez a viszonyulás körvonalazódott a vallástanárok esetében is, akik valószínúleg tantárgyuknál fogva is, nagyon hangsúlyozták az elfogadás, a kölcsönös bizalom és tisztelet fontosságát. „...át kell érezzed, kell értsed őket, kell szeressed, s el kell fogadjad” (vallástanár 2). Feladatuknál fogva a fejlesztő, felzárkóztató pedagógusok ${ }^{9}$ szintén a roma gyermekek helyzetének megértését, a tanulás egyéni ütemének figyelembevételét, a játékos, életszerű gyakorlatok előtérbe helyezését emelték ki. Az ehhez a típushoz tartozó pedagógusok osztályaiban általában kevés a hiányzás, a lemorzsolódás, a gyermekek szeretnek iskolába járni.

A szabálytisztelő típus megpróbál szigorúan ragaszkodni az iskolai szabályok, szabályzatok betartatásához, betartásához. Számára fontos, hogy lépést tartson a tantervvel, hogy a tanórákon szigorúan a tananyagot dolgozza fel. Elsődlegesnek tekinti a teljesítmények elérését, a sikeres vizsgaszereplést, és szerinte a „lemaradt”, „nem tanuló” gyermekek ebben akadályozzák az osztályt és a pedagógust. „Hivatali" szerepéből nem lép ki, a gyermekek otthoni helyzete, problémái iránt nem érdeklődik, a „felelőtlen” szülőkkel kevés a találkozása. Az ilyen típusú pedagógusok osztályaiban a „nem teljesítő” tanulók nem érzik jól magukat, egyre többet hiányoznak, amely szigorú következményekkel jár számukra: levonják a magaviseletüket, osztályt ismételnek, vagy nem zárják le őket a félév végén. Innen egyenes út vezet a korai iskolaelhagyáshoz, amely mind a pedagógusnak, mind a gyermeknek „megnyugvást hoz”. „Fóleg a vizsgatantárgyakat tanító tanárok vannak bajban, mert ők a vizsgára való felkészítés miatt nem nagyon szelektálhatnak az anyagból, a tantervet is napirenden követniük kell. A gyermekek nagy része már ötödik-hatodikban feladja, egymást is negatívan befolyásolják. Nyolcadikra már kevesen vannak, akik valamenynyire tanulnak... A roma gyermekek otthon nem is tanulnak, nincs is ahogy, nekik nem segít a szülő, ők még hamarabb feladják" (osztályfőnök 5).

Ahogy az osztályokban gyarapodik a roma tanulók száma, úgy egyre nehezebb betartani a szabályokat, a tantervi előírásokat, ezért a roma többségű iskolákban, osztályokban kevés pedagógus tartozik a „szabálytisztelő" típusba. Az ehhez a típus-

${ }^{9}$ A nagyszámú roma és/vagy hátrányos helyzetű tanulót tömörítő iskolákban lehetőség van egyegy fejlesztő, felzárkóztató pedagógus alkalmazására, aki egyénileg, vagy kiscsoportokban foglalkozik a tanulókkal. Az általam kiválasztott iskolákban mindenhol volt egy fejlesztő pedagógus, aki segíteni próbált a tanulási nehézséggel küzdő gyermekek fejlesztésében, felzárkóztatásában. Mindenhol elmondták, hogy sokkal több ilyen segítő szakemberre lenne szükség. 


\section{TEMATIKUS TANULMÁNYOK - Székelyföld - térség és társadalom}

hoz tartozó pedagógusok leginkább a felső tagozaton, vegyes osztályokban, vizsgatantárgyat, idegen nyelvet tanítanak, gyakran pályakezdők, akik az egyetemen tanultakat próbálják gyakorlatba ültetni.

A vívódóak típusa mind a rendszer előírásainak, mind a gyermekek elvárásainak megpróbál megfelelni. Megpróbálja közelíteni a kettőt, kisebb-nagyobb engedményeket tesz hol az egyik, hol a másik irányba. Szituatív döntéseket hoz, mindig az adott helyzetnek megfelelően. Mivel általában igen nagy a szakadék a gyermekek előzetes tudása, képességei és a megtanítandó tananyag között, nehezen közelíthető a kettő egymáshoz. A folyamatos „egyensúlyozgatás” sok energiát követel, az oda-vissza játékban kevésbé látványosak az eredmények. „....amúgy is nehéz egy vizsgatantárgyat tanítani, és 8 . osztály végén egy országos versenyre, megmérettetésre kell előállítani őket, aminek az eredményétől függ, hogy hová jutnak be (melyik középiskolába). Oda eljutni mondjuk egy második osztályos szintről, nagyon nehéz feladat Nem is sikerült két év alatt. A leggyengébbnek látszó eredmény mögött is rengeteg munka van." (vizsgatantárgyat tanító tanár 1).

Sok a frusztráció, a bizonytalanság, állandó a szerepkonfliktus, amely hosszútávon önértékelési problémákhoz, akár kiégéshez vezethet. „... minden osztályban vannak olyan tanulók, akik diszkalkuliások, diszlexiások, diszgráfiások vagy figyelemzavaros gyerekek. Ezekre külön mind figyelni néha lehetetlen Tehát nem is lehet minden alkalommal differenciálni, függ a tananyagtól, függ, hogy elméleti vagy gyakorlati óra van. Gyakorlati órákon inkább lehet." (vizsgatantárgyat tanító tanár 2). Erre a helyzetre a pedagógusok különböző módon reagálnak, különböző túlélési stratégiákat (mentálhigiéniai programon való részvétel, továbbképzés, önképzés, figyelemváltás, bürokratizálódás, elmenekülés stb.) alkalmaznak. A megkérdezett pedagógusok jelentős többsége ebbe a típusba tartozik, túlélési stratégiáik viszont igen változatosak. Ezek alakulását nagymértékben befolyásolja a pedagógus személyisége, neveltetése, rezilienciája, illetve annak az iskolának a klímája, közössége, nevelési kultúrája, amelyben dolgozik. Akik kihívásként tekintenek a helyzetre és önképzéssel, szakemberi segítséggel, képzésekkel működő megoldásokat találnak, azok egyre ritkábban „veszítik el az egyensúlyukat”. „Sokat segített, amikor elmentem mentálhigiénés képzésre, és nagyon sok olyan helyzetgyakorlat volt, amelyben az empátiát gyakoroltuk, illetve amikor esetmegbeszélések voltak (...) megtanultam, hogy próbáljunk mindig a probléma mögé nézni. Ez egy ilyen rutin lett. Ha a gyermek elmond valamit, próbálom a hátterét megérteni, emiatt könnyebb lett az elfogadás" (tanító 3). Nyitottabbá, elfogadóbbá tudnak válni, amelynek pozitív következményei az osztályban, a tanteremben is érezhetőek lesznek. Akiknek ez nem sikerül, azok a folyamatos „őrlődés” miatt gyakran bezárkóznak, „energiatakarékosan”, már-már robotszerűen végzik a dolgukat, „túlélnek”. Papíron minden rendben van, látszólag nincsenek problémák. Nincs kötődés a gyermekekhez, leginkább a „ha jön jó, ha kimarad, az ő baja” viszonyulás a jellemző. „Volt, hogy úgy felidegesítettem magam, a 


\section{TEMATIKUS TANULMÁNYOK - Székelyföld - térség és társadalom}

vérnyomásom úgy felment, hogy a vérnyomáscsökkentőt be kellett vegyem. Nap mint nap ez nagyon rossz. (...) Most próbálom úgy csinálni, hogy a vállamról lepereg, Most már az az igazság, hogy ott vagyok abban a korban, hogy én tudom, hogy nekem még öt évet kell tanítsak, a saját gyerekeim és unokáim foglalkoztatnak. Nem az, hogy most én továbbképzőre menjek. És hát az egészségügyi problémáim, így védem meg magam, próbálom engedni, lefolyik rólam" (nem vizsgatantárgyat tanító 3).

Vannak, akik a túlélés érdekében áthelyezik a hangsúlyokat, és iskolán kívül szereznek maguknak sikerélményt (például második állás keresésével). Vagy egyszerűen kilépnek a helyzetből, másik iskolára vagy másik pályára váltanak." Volt olyan tanárunk, aki az első pár hét után feladta, azt mondta, hogy ő ezt nem tudja csinálni" (aligazgató 2).

\section{Összegzés}

A roma oktatást szabályozó országos dokumentumok, törvények, kormánystratégiák hangzatos, EU-konform célkitűzései az iskolák hétköznapi világában nehezen vagy egyáltalán nem valósulnak meg. Konkrét operatív programok, megfelelő források hiányában továbbra is csak célkitűzések maradnak, amelyeket időről időre frissítenek, kiegészítenek, módosítanak. Bár a minőségi oktatáshoz mindenkinek hozzá kellene férnie, a politikai instabilitás, az oktatásra fordított alacsony összegek, ${ }^{10}$ a tanügyminiszterek folyamatos cserélődése ${ }^{11}$ és megalapozatlan reformtörekvéseik közepette maga a minőségi oktatás is veszélyben van. Az alulról szerveződő kezdeményezések „csak lelkesedéssel” hosszútávon nehezen fenntarthatóak, szükség volna a roma oktatás eredményességét is elősegítő összehangolt, átfogó, térségi szintű stratégiák, közpolitikák, módszertanok kidolgozására és a tervezett intézkedésekhez a források előteremtésére. A térségben „a roma lakosság helyzetével kapcsolatos tematizáció gyakorlatilag hiányzik. Ez nem csupán a téma háttérbe szorítására utal, hanem a társadalmi és szakmai tematizációhoz szükséges tudások (ismeretek és kompetenciák) hiányos voltára is" (Biró 2017: 142). Kevés a diagnosztizáló jellegű kutatás is, amely segítené a helyzetismeretet, a helyzetértelmezést, és alapul szolgálhatna a továbblépéshez. Fontos lenne ismerni az összehangolt, térségi szintű stratégiák potenciális kidolgozóinak, a településvezetőknek, helyi eliteknek a „roma kérdéshez" való viszonyulását, az eddigi eredményeket, a különböző projektek „hozadékát”, szükség volna az utóbbi évek szociálpolitikai intézkedéseinek hatékonyságát feltáró elemzésekre, a roma lakosság gazdasági, szociális helyzetét, migrációs gyakorlatát, az iskolázott roma fiatalok (akik legalább középiskolát végeztek) helyzetét vizsgáló kutatásokra.

\footnotetext{
${ }^{10}$ 2017-ben a GDP 3,1 százaléka jutott az oktatásra.

111989 decembere óta a 25. tanügyminiszter került kinevezésre.
} 


\section{TEMATIKUS TANULMÁNYOK - Székelyföld - térség és társadalom}

Az általam bemutatott előzetes kutatási eredmények csupán a problémák egy szűk vetületét tárják fel, a roma gyermekeket oktató pedagógusok viszonyulását, attitűdjét próbálják megragadni egy földrajzilag behatárolt területen. Intézményesült megoldások hiányában azt gondolom, hogy ezeknek a pedagógusi viszonyulásoknak igen fontos szerepük van a roma gyermekek iskolai pályafutásának alakulásában. A felvázolt típusok alapján megállapítható, hogy nem minden pedagógus alkalmas arra, hogy roma többségű iskolákban, osztályokban eredményesen tanítson. Fontos lenne, hogy a „nehezített pályára” olyan pedagógusok kerüljenek, akik kellően problémaérzékenyek, nyitottak és rugalmasak, akik képesek a reflektivitásra és a szakmai megújulásra. Sajnos az érvényben levő jogszabályok nem teszik lehetővé az iskolavezetők számára, hogy intézményük részére maguk „válasszanak” pedagógusokat, ${ }^{12}$ így a „kihelyezett” pedagógusokat gyakran „menet közben” kell érzékenyíteni, felkészíteni, továbbképezni. A roma többségű iskolákban igen magas a fluktuáció, a nehezített körülmények, az iskolák alacsony presztízse kevésbé vonzó a pedagógusok számára.

A vívódó pedagógusok nagy száma arra enged következtetni, hogy az integrációs folyamat nem zökkenőmentes, hogy sok a bizonytalanság, a kísérletezgetés. A pedagógusok gyakran szembesülnek azzal, hogy az eddig bejáratott (tanult) módszereik nem múködnek, hogy változtatniuk kell mind az óraszervezés, mind az alkalmazott módszerek tekintetében. A pedagógusképzés hiányosságai, az alacsony számú hatékony továbbképzési lehetőség, a hasonló helyzetben levő pedagógusok tapasztalatcseréjének hiánya mind-mind olyan tényezők, amelyek tovább erősítik a „vívódást”, az egyéni megoldáskeresést, amely nem kedvez a sikerességnek, eredményességnek.

\section{Irodalom}

Babusik F. (2003): Késői kezdés, lemorzsolódás - cigány fiatalok az általános iskolában epa.oszk.hu/00000/00035/00075/2003-10-ta-Babusik-Kesoi.html. Utolsó letöltés: 2019.05.23.

Bacskai K. (2015): Iskolák a társadalom peremén. Belvedere, Szeged.

Biró A. Z. - Oláh S. (2002): Helykeresők. Roma népesség a Székelyföldön. In: Bodó Julianna (szerk): Helykeresők? Roma lakosság a Székelyföldön. KAM - Regionális és Antropológiai Kutatások Központja, Pro-Print Könyvkiadó, Csíkszereda.

Biró A. Z. (2017): Roma helyzetkép a térségben. In: Biró Z, Jakab J (szerk.): Tegnap és ma. Romakutatások a székelyföldi térségben. KAM - Regionális és Antropológiai Kutatások Központja, Státus Kiadó, Madéfalva.

\footnotetext{
${ }^{12}$ A pedagógusok „szétosztása” az iskolákban egy központilag szabályozott eljárás alapján történik, az ún versenyvizsgán szerzett jegy alapján kerülnek egy-egy intézményhez. Ha nincs végleges állásuk, akkor kétévente versenyvizsgáznak, és újra iskolát „választanak” maguknak.
} 


\section{TEMATIKUS TANULMÁNYOK - Székelyföld - térség és társadalom}

Deci, E., L. - Ryan R., M. (2008): Self-Determination Theory: A Macrotheory of Human Motivation, Development, and Health. Canadian Psychology, 49(3): 182-185.

Eccles, J. S. (2004): Schools, Academic Motivation and Stage-Environment Fit. In Lerner, R, M. - Steinberg L. (eds.): Handbook of Adolescent Psychology 125-154. New Jersey: John Wiley - Sons.

Falus I. - Golnhofer E. (1989): A pedagógia és a pedagógusok: egy empirikus vizsgálat eredményei. Akadémia Kiadó, Budapest.

Fosztó L. (2003): Szorongás és megbélyegzés: a cigány-magyar kapcsolat gazdasági, demográfiai és szociokulturális dimenziói. In: Bakó Boglárka (szerk.): Lokális világok. Együttélés a Kárpát-medencében, MTA Társadalomkutató Központ, Budapest.

Hanushek, E. A. - Kain, J. F. - Rivkin S. J. O. (2005): The Market for Teacher Quality. NBER, Cambridge.

Howes, C. (2000): Social-emotional classroom climate in child care, child-teacher relationships and children's second grade peer relations. Social Development, 9(2): 191-204.

Insitutul National de Statistica (INSS) - Országos Statisztikai Hivatal: Educatie (Oktatás) - Numar elevi pe nivele, judete si limba de predare (Tanulók száma oktatási szintenként, megyénként és a tanítás nyelve szerint) statistici.insse.ro:8077/ tempo-online/\#/pages/tables/insse-table. Utolsó letöltés: 2019.05.23.

Ionescu, M. - Cace, S. (2006): Politici publice pentru romi. Evoluții și perspective. (Közpolitikák romáknak. Eredmények és kilátások). Expert, București.

Jigau, M. - Surdu, M. (eds.) (2002): Participarea la educatie a copiilor romi. Probleme, solutii, actori. (A roma gyermekek iskolai részvétele. Problémák, megoldások, szereplők). Ministerul Educaţiei şi Cercetării, Institutul de Ştiinţe ale Educaţiei, ICCV, Editura MarLink, Bucureşti.

Kacsó-Dávid Á. (2017): Útvesztő: roma gyermekek a romániai oktatási rendszerben. Erdélyi Társadalom, 15(1): 43-56.

Kinda I. (2007): „A téglavetéssel erőssen nagy baj van...” Fejezetek a nagyborosnyói cigányok gazdasági és társadalomnéprajzi kutatásából. Acta Siculica. Székely Nemzeti Múzeum, Sepsiszentgyörgy.

Kiss T. - Barna G. (2012): Népszámlálás 2011. Erdélyi magyar népesedés a XXI. század első évtizedében. Demográfiai és statisztikai elemzés. Nemzeti Kisebbségkutató Intézet, Kolozsvár. http://www.ispmn.gov.ro/uploads/ISPMNN_WP_43-1904\%20BT.pdf. Utolsó letöltés: 2019.05.05.

Kiss T. (2009): Categorizare etnică și statut social la Valea Crișului, județul Covasna [Etnikai kategorizáció és társadalmi státus Kőrispatakon, Kovászna megyé- 


\section{TEMATIKUS TANULMÁNYOK - Székelyföld - térség és társadalom}

ben] In: Incluziune și excluziune. Studii de caz asupra comunităţilor de romi din România, szerk. Kiss T. - Fosztó L. - Fleck G., Editura Institutului pentru studierea problemelor minorităților naționale, Cluj-Napoca, 83-117.

Kulcsár L. - Varga N. - Obádovics Cs. (2013): Informális gazdasági magatartások és szívességi szolgáltatások egy interetnikus erdővidéki faluban. Gazdaság és Társadalom. 111-129.

Liskó I. (2001): A cigány tanulók és a pedagógusok. In: Andor Mihály (szerk.): Romák és oktatás. Iskolakultúra, Pécs. 31-46. http://mek.oszk.hu/01900/01964/01964. pdf. Utolsó letöltés: 2018.07.05.

Moisa, F. (2016): Startegii DA, finantare NU. (Stratégia IGEN, finanszírozás NEM). Mecanismele de finantare a politicilor publice pentru romi in Romania. Fundația Centrul de Resurse pentru Comunitățile de Romi, Cluj Napoca.

Nagy J. (2002): XXI. század és nevelés. Osiris Kiadó. Budapest.

Oláh S. (1996): Cigány-magyar kapcsolatok. In:Gagyi József (szerk.): Egymás mellett élés. A magyar-román, magyar-cigány kapcsolatokról, KAM - Regionális és Antropológiai Kutatások Központja, Pro-Print Könyvkiadó, Csíkszereda.

O.M.E.N. 3363 din 1 martie 1999 privind încadrarea prin concurs a inspectorilor rromi/pentru rromi [A roma oktatásért felelő tanfelügyelők kinevezését szabályozó 3363-as számú 1999-es határozat].

Ordin nr. 1.540 din 19 iulie 2007 privind interzicerea segregării şcolare a copiilor romi şi aprobarea Metodologiei pentru prevenirea şi eliminarea segregării şcolare a copiilor romi [A roma gyermekek iskolai szegregációját tiltó 1540-es számú 2007-es Rendelet] Monitorul Oficial al României, Partea I, nr. 692 din 11 octombrie 2007.

Ordinul cadru privind interzicerea segregării școlare în unitățile de învățământ preuniversitar nr. 6134/2016 [Az iskolai szegregációt tiltó 6134-es számú 2016-os Rendelet] https://lege5.ro/Gratuit/ge2dembygy4a/ordinul-nr-6134-2016-privind-interzicerea-segregarii-scolare-in-unitatile-de-invatamant-preuniversitar . Utolsó letöltés: 2019.03.05.

Peti L. (2007): Adaptálódás és szegregáció. A kulturális különbségek kommunikálása a cigány-magyar együttélésben egy Kis-Küküllő-menti településen. A Csíki Székely Múzeum Évkönyve. 2007-2008.

Polónyi I. - Timár J. (2001): Tudásgyár vagy papírgyár? Új Mandátum Könyvkiadó, Budapest.

Pozsony F. (2003): Magyarok, románok és cigányok a háromszéki Zabolán. In: Bakó Boglárka (szerk.): Lokális világok. Együttélés a Kárpát-medencében, MTA Társadalomkutató Központ, Budapest. 


\section{TEMATIKUS TANULMÁNYOK - Székelyföld - térség és társadalom}

Raportul Grupului Băncii Mondiale: Ce este necesar pentru realizarea incluziunii romilor in Romania? 28 februarie 2014. pag. 27. (Világbanki Jelentés: „Mire van szükség a romániai romák inklúziójához?" 2014. február 28. http://www.worldbank.org/content/dam/Worldbank/document/eca/romania/Summary\%20Report\%20RomanianAchievingRoma\%20Inclusion\%20R0. pdf. Utolsó letöltés: 2019.05.23.

Szabó Á. T. (2003): Határképzés - egy multietnikus falu térszerkezete. In: Dimény Attila - Szabó Á. T. (szerk.): Népi kultúra, társadalom Háromszéken. Kriza Könyvek 17. Kriza János Néprajzi Társaság, Kolozsvár. 120-129.

Zamfir, E. - Zamfir, C. (1993): Tiganii intre ignorare si ingrijorare, Bucuresti, Alternative.

Wigfield et aI., (2006): Development of Achievement Motivation. https://www.researchgate.net/publication/228017465_Development_of_Achievement_Motivation. Utolsó letöltés: 2018.07.05 